\title{
Reading and Mathematics Differences for English Language Learners Enrolled in Dual Language or Exit Programs
}

\author{
By Julia D. Trevino Mendez* \\ John R. Slate t $^{*}$ \\ Cynthia Martinez-Garcia ${ }^{*}$
}

In this investigation, the relationship between bilingual education program type (i.e., dual language programs or exit programs) and English Language Learner reading and mathematics test scores was examined. Data were obtained on English Language Learners who were enrolled in Grades 3, 4, 5, and 6 in Texas public schools for the 2008-2009, 2009-2010, and 2010-2011 school years. In all 24 analyses, the reading and mathematics scores of English Language Learners who attended a dual language program were consistently higher than the scores of the English Language Learners who were enrolled in an exit program. As grade level increased from Grade 3 to Grade 6, the achievement gap in reading and in mathematics between dual language and exit programs also increased.

Keywords: bilingual education program, dual language program, exit program.

\section{Introduction}

Educators have been faced the challenge of having to instruct students with linguistic and cultural differences for a long time (Yturriago \& Garcia, 2014). A lengthy and turbulent educational and legal history lies behind the integration of English Language Learners into the U.S. educational system, including legal and political decisions regarding the adequacy and availability of language acquisition programs for English Language Learners (Flores, Batalova, \& Fix, 2012). Thus, federal law requires the provision of adequate English language development support for English Language Learners, as well as an annual proficiency assessment (Samson \& Collins, 2012).

According to the Texas Administrative Code (2012, p. 1), "the terms English language learner and limited English proficient student are used interchangeably". Statistically significant differences have been documented in the test scores of English Language Learners by ethnic/racial classification; with Asian students constituting the highest performing English Language Learners, followed by White students. Black and Hispanic English Language Learners are the lowest performing groups (Flores, Batalova, \& Fix, 2012). High school graduation rates of Hispanic English Language Learners, 53.2\%,

\footnotetext{
* Assistant Principal, Spence Elementary School, USA.

${ }^{\dagger}$ Professor, Sam Houston State University, USA.

* Associate Professor, Sam Houston State University, USA.
} 
are statistically significantly lower than graduation rates of White English Language Learners, 75\% (Ortiz, Pagan, Warford, \& Wendell, 2009).

In 2010, President Barack Obama published a Blueprint for Reauthorization of the Elementary and Secondary Education Act. In this document, President Obama acknowledged his commitment to providing equity of opportunity for English Language Learners. He also recognized the responsibility of America's schools of meeting the educational needs of this group of students. In this document, President Obama perceived the importance of the utilization of an evaluation system of the educational programs regarding language instruction.

To meet the educational needs of minority language students, different modalities of bilingual education programs have been developed over time. Cazden and Snow (1990) referred to the term bilingual education as "a simple label for a complex phenomenon" (p. 9). According to Baker (2006), "the term [is] ambiguous and imprecise" (p. 192). The Commissioner's Rules (Chapter 89) regarding Adaptations for Special Populations; Subchapter BB Concerning State Plan for Educating English Language Learners ascertained that:

The bilingual education program shall be a full-time program of instruction in which both the students' home language and English shall be used for instruction. The amount of instruction in each language within the bilingual education program shall be commensurate with the students' level of proficiency in each language and their level of academic achievement. (Texas Administrative Code, 2012, p. 5)

Bilingual education has been classified in many different ways over time. In 1970, Mackey developed an exhaustive categorization of bilingual education, presenting 90 patterns of bilingual schooling. Rhodes, Ochoa, and Ortiz (2005) acknowledged the existence of five types of English instruction programs in the United States. Furthermore, Rhodes et al. (2005) classified these programs into bilingual (i.e., transitional, one-way dual language, and two-way dual language) or English as a Second Language (i.e., content based and pullout). In 1990, Baker presented 10 types of bilingual education programs and categorized these programs into weak forms of education for bilingualism (i.e., submersion structured immersion, submersion with withdrawal classes/sheltered English, segregationist, transitional, mainstream with foreign language teaching, and separatist), and strong forms of education for bilingualism and biliteracy (i.e., immersion, maintenance/heritage language, two-way/dual language, and mainstream bilingual).

Baker (1990) suggested that a differentiation should be made between those programs in which bilingualism is used and promoted, and the programs for language minority students in which bilingualism is not promoted. According to Baker (1990), the goal of transitional bilingual education is to shift minority language students from their home language to the dominant language. Transitional bilingual education fosters social and cultural assimilation. 
Transitional bilingual education promotes a language shift in minority language students (Garcia, 2011). The goal of transitional bilingual education is to help minority students acquire and increase their English skills (Rennie, 1993; Tong, Irby, Lara-Alecio, \& Mathes, 2008). According to Tong et al. (2008), transitional bilingual education is the most commonly used bilingual education program in the United States. Transitional early-exit bilingual programs have been designed with the objective of helping minority-language students transition from their native language into an English-only instructional classroom (Gallo, Garcia, Pinuelas, \& Youngs, 2008). Students who attend these programs receive instruction in the minority language, as well as in the majority language (Ramirez, 1986). Early-exit programs serve groups of students who share the same minority language background. To the extent necessary, these programs provide academic content instruction in the minority language (Gallo et al., 2008). Students who attend early-exit programs are first taught how to read in their home language (Ramirez, 1986).

Students who attend late-exit transitional programs receive balanced academic instruction in their minority language and the majority language from kindergarten through Grade 6 (Collier, 1992; Crawford, 1989). Between 40\% and $50 \%$ of the instructional day through Grade 6 of minority language students enrolled in a late-exit program takes place in their first language (Ramirez, 1986). Instruction in the majority language starts in Grades 2 or 3 for students enrolled in late-exit programs (Collier, 1992; Crawford, 1989).

In a recent investigation, Martinez (2014) examined differences in student reading and mathematics achievement between early-exit and late-exit bilingual programs in Texas. In her research, 72 analyses of the reading and mathematics performance of English Language Learners in Grades 3-6 who attended either a late-exit or an early-exit program were conducted for the 2008-2009, 2009-2010, and 2010-2011 school years. Results from Martinez's (2014) investigation were mixed. English Language Learners who were enrolled in late-exit bilingual education programs outperformed English Language Learners in early-exit bilingual education programs in 57\% (i.e., 41 out of 72) of the analyses. English Language Learners enrolled in early-exit programs outperformed English Language Learners in late-exit programs in $43 \%$ (i.e., 31 out of 72 ) of the analyses.

Additionally, Martinez (2014) examined differences between English Language Learner boys and girls in Grades 3, 4, 5, and 6 in early-exit and lateexit bilingual programs with regard to reading for the 2008-2009, 2009-2010, and 2010-2011 school years. English Language Learner boys who were enrolled in late-exit bilingual education programs outperformed English Language Learner boys in early-exit bilingual education programs in 58\% (i.e., 7 out of 12) of the analyses. English Language Learner girls enrolled in lateexit programs outperformed English Language Learner girls in early-exit programs in $100 \%$ (i.e., 12 out of 12) of the analyses.

Martinez also (2014) analyzed differences between English Language Learner boys and girls in Grades 3, 4, 5, and 6 in early-exit and late-exit bilingual programs concerning mathematics for the 2008-2009, 2009-2010, and 
2010-2011 school years. English Language Learner boys who were enrolled in late-exit bilingual education programs outperformed English Language Learner boys in early-exit bilingual education programs in $58 \%$ (i.e., 7 out of 12) of the analyses. English Language Learner girls enrolled in late-exit programs outperformed English Language Learner girls in early-exit programs in 67\% (i.e., 8 out of 12) of the analyses.

In regard to the maintenance bilingual education, Baker (1990) indicated that the dual language or two-way programs are a strong form of education in bilingualism and biliteracy. Dual language education involves equal amounts of minority and majority students learning together in a classroom. Both languages are used in equal amounts of time for teaching and learning, which develops nearly balanced bilinguals (Baker, 1990; Lindholm, 1991; LindholmLeary, 2001; Morison, 1990).

In the United States, two main variants of the dual language education model exist: the 90:10 and the 50:50 models. The difference between these two models lies on how the languages are distributed for instruction and in the language in which reading is taught. In the 90:10 model, the amount of time each language is used throughout the instructional day varies across the grade levels, whereas in the 50:50 models, languages of instruction are used half of the instructional day each (Lindholm-Leary, 2012). Dual language education classes consist of two groups of students (i.e., English Language Learners and English only or English dominant), all integrated within the cohort (Collier 1992).

In 1998, a school district with a long history of academic failure received a grant for $\$ 1.5$ million to implement a five-year pilot dual-language program with a 50:50 language distribution in which all subjects were taught in English and Spanish. The dual-language program was implemented at a kindergarten through Grade 4 school with a student population of about 550 students, 33\% of which were English Language Learners. About $57 \%$ of the students spoke English only or were English dominant. About $98 \%$ of the students who attended this campus were on free or reduced lunch programs (DeJesus, 2008).

DeJesus (2008) compared the Language Arts achievement scores for the 2001-2002 school year for students in Grade 4 who had participated in the dual-language program for four or five years (i.e., English Language Learners and English dominant) to the Language Arts achievement scores of other students in the school district (i.e., general education and transitional bilingual). English Language Learners and English dominant students who were enrolled in the dual-language program outperformed general education students by $33 \%$ (i.e., $80 \%$ vs. 47\%). Furthermore, English Language Learners and English dominant students who were enrolled in the dual-language program outperformed transitional-bilingual students by $55 \%$ (i.e., $80 \%$ vs. $25 \%$ ).

When comparing the Language Arts achievement scores for the 2002-2003 school year for students in Grade 4 who had participated in the dual-language program for four or five years (i.e., English Language Learners and English dominant) to the scores of other students in the school district (i.e., general education and transitional bilingual), DeJesus (2008) established that English 
Language Learners and English dominant students who were enrolled in the dual-language program had outperformed general education students by $20 \%$ (i.e., 59\% vs. 39\%). Furthermore, DeJesus (2008) documented that English Language Learners and English dominant students who were enrolled in the dual-language program outperformed transitional-bilingual students by $22 \%$ (i.e., 59\% vs. 37\%). Dual-language students were the highest performing cohort in the school and in the district.

\section{Purpose of the Study}

The purpose of this study was to examine the extent to which differences were present in student academic achievement between dual language immersion programs and transition bilingual education programs. Through obtaining and analyzing archival data from the Texas Education Agency Public Education Information Management System, the extent to which the reading and mathematics achievement of English Language Learners in Grades 3, 4, 5, and 6 across a 3 -year period differs as a function of the particular program in which they were enrolled was determined.

\section{Significance of the Study}

Research in the area of second language acquisition is important. With an annual enrollment growth of $10 \%$, English Language Learners and immigrant students have been the fastest growing student subgroup in the United States for the past 10 years. Thus, the numbers of English Language Learners and immigrant students in the nation have increased tremendously, from $10 \%$ of the student enrollment in 1990 to $13 \%$ of the student enrollment in 2005. By 2020, $25 \%$ of the student population in the United States are estimated to be English Language Learners (Ortiz et al., 2009).

Fry (2008) declared that most English Language Learners (76\%) in the nation speak Spanish at home. However, the U.S. Department of Education reported in 2008 that English Language Learners who attend school in the United States speak more than 460 different languages. About $70 \%$ of the English Language Learners in the nation are educated in Arizona, California, Florida, New York, and Texas (Leos \& Saavedra, 2010). Hence, to gain access to valuable information that may allow educational leaders to make decisions that will positively influence the learning process of the English Language Learners in the state of Texas, the differences in bilingual education programs (i.e., dual language versus exit) must be analyzed.

In 2009, the National Center for Education Statistics reported an achievement gap of about $30 \%$ between English Language Learners in Grades 4 through 8 who took the National Assessment for Educational Progress in reading and in mathematics and their monolingual counterparts. English Language Learners also have low high school graduation rates and low college 
placement rates (Fry, 2003). With English Language Learners having the highest dropout rates, it is important that additional research regarding the most effective way to educate English Language Learners is conducted.

\section{Research Questions}

In this investigation, the following research questions were addressed: (a) What is the difference in the academic achievement (i.e., reading and mathematics) of Grade 3 English Language Learners as a function of bilingual education program (i.e., dual language or exit program)?; (b) What is the difference in the academic achievement (i.e., reading and mathematics) of Grade 4 English Language Learners as a function of bilingual education program (i.e., dual language or exit program)?; (c) What is the difference in the academic achievement (i.e., reading and mathematics) of Grade 5 English Language Learners as a function of bilingual education program (i.e., dual language or exit program)?; and (d) What is the difference in the academic achievement (i.e., reading and mathematics) of Grade 6 English Language Learners as a function of bilingual education program (i.e., dual language or exit program)? These four research questions were repeated for the 2008-2009, 2009-2010, and 2010-2011 school years.

\section{Method}

\section{Research Design}

A nonexperimental research design (Kerlinger, 1986) was employed in this empirical quantitative investigation. Nonexperimental research has been defined by Kerlinger (1986) as studies in which independent variables are not directly manipulated by the researcher because they have already occurred. Because the English Language Learners whose reading and mathematics data were analyzed herein had already been enrolled in either a dual language immersion program or in a transitional bilingual program, no manipulation of the independent variable was possible. Furthermore, because the TAKS Reading and Mathematics tests had already been taken by these students, the dependent variables could not be manipulated either.

\section{Participants}

In this investigation, archival data were obtained from the Texas Education Agency Public Education Information Management System regarding English Language Learners in Grade 3, 4, 5, and 6 in Texas public schools for the 2008-2009, 2009-2010, and 2010-2011 school years. Participants whose data were analyzed herein were all English Language Learners enrolled in Texas public schools for the 2008-2009, 2009-2010, and 2010-2011 school years who 
participated in either a dual language immersion program or a transitional bilingual program. In addition, to ascertain the difference in academic achievement between the different types of bilingual education programs that was analyzed in this study, if any, participation in the preceding programs was analyzed along with Texas Assessment of Knowledge and Skills (TAKS) Reading and Mathematics scores. Moreover, academic achievement among grade levels was analyzed.

Data on English Language Learners enrolled in charter or private schools were not included in these analyses. The enrollment numbers of bilingual and English as a Second Language students in Texas public schools for the 20082009, 2009-2010, and 2010-2011 school years were 757,824 students, 779,771 students, and 797,683 students, respectively (Texas Education Agency, 2014).

\section{Instrumentation}

For the purpose of this article, three years of archival data (i.e., 2008-2009, 2009-2010, and 2010-2011) for English Language Learners in Grades 3 through 6 who attended Texas public schools were collected from the Texas Education Agency Public Education Information Management System. The TAKS Reading and Mathematics test scores of English Language Learners in Grades 3 through 6 in Texas public schools were analyzed to determine to which extent, if any, a difference was present as a result of the participation of this group of students in a dual language immersion program or a transitional bilingual education program. For detailed information about the reliability and validity of the TAKS Reading and Mathematics test scores, readers are directed to the Texas Education Agency website. Extensive psychometric testing, conducted by the TAKS test developers, provides documentation that the TAKS Reading and Mathematics test scores exhibit high degrees of reliability and validity.

\section{Results}

In this section, the research questions previously delineated are examined by grade levels. Results for the lower elementary grade levels are reported first. Prior to calculating the statistical procedures, the underlying assumptions of data normality were checked.

\section{Reading and Mathematics Results for Grade 3 Students}

With respect to the 2008-2009 school year, a statistically significant difference was present in Grade 3 students' TAKS Reading raw scores, $t(31262.81)=12.28, p<.001, d=0.11$, trivial effect size, and in their TAKS Mathematics raw scores, $t(30467.69)=5.12, p<.001, d=0.04$, trivial effect size, by the type of bilingual education program in which they were enrolled. Grade 3 students who were enrolled in the dual language programs had higher 
average TAKS Reading test scores (i.e., 0.78 points higher) and Mathematics test scores (i.e., 0.33 points higher) than did Grade 3 students in the exit programs. Descriptive statistics for this analysis are presented in Table 1.

Table 1. Descriptive Statistics for Reading and Mathematics Scores by Bilingual Education Program for Grade 3 Students in the 2008-2009, 20092010, and 2010-2011 School Years

\begin{tabular}{|l|c|c|c|}
\hline $\begin{array}{l}\text { Academic Subject, School Year, and } \\
\text { Bilingual Education Program Type }\end{array}$ & $\mathbf{n}$ & $\mathbf{M}$ & SD \\
\hline Reading & & & \\
\hline $2008-2009$ & & & \\
\hline Exit & 47,795 & 27.46 & 7.19 \\
\hline Dual Language & 17,483 & 28.24 & 7.15 \\
\hline $2009-2010$ & & & \\
\hline Exit & 46,420 & 27.54 & 7.26 \\
\hline Dual Language & 21,674 & 28.15 & 7.15 \\
\hline $2010-2011$ & & & \\
\hline Exit & 43,688 & 27.34 & 7.32 \\
\hline Dual Language & 26,097 & 28.23 & 7.12 \\
\hline Mathematics & & & \\
\hline $2008-2009$ & & & \\
\hline Exit & 48,113 & 31.01 & 7.21 \\
\hline Dual Language & 17,342 & 31.34 & 7.26 \\
\hline $2009-2010$ & & & \\
\hline Exit & 46,420 & 30.88 & 6.92 \\
\hline Dual Language & 21,665 & 31.19 & 6.99 \\
\hline $2010-2011$ & & & \\
\hline Exit & 43,691 & 31.37 & 6.74 \\
\hline Dual Language & 26,098 & 31.65 & 6.89 \\
\hline
\end{tabular}

Regarding the 2009-2010 school year, a statistically significant difference was revealed in Grade 3 students' TAKS Reading raw scores, $t(42907.35)=$ $10.21, p<.001, d=0.08$, trivial effect size, and in their TAKS Mathematics raw scores, $t(41929.98)=5.36, p<.001, d=0.04$, trivial effect size, by the type of bilingual education program in which they were enrolled. Higher average scores were obtained on the TAKS Reading test ( 0.60 points higher) and on the TAKS Mathematics test $(0.31)$ by Grade 3 students who were enrolled in the dual language programs than by their counterparts who were enrolled in the exit programs.

Concerning the 2010-2011 school year, a statistically significant difference was present in Grade 3 students' TAKS Reading raw scores, $t(56132.81)=15.82$, $p<.001, d=0.12$, and in their TAKS Mathematics raw scores, $t(53888.44)=5.14$, $p<.001, d=0.04$, by the type of bilingual education program in which they were enrolled. The effect sizes for these two statistically significant differences were both trivial. Congruent with the results for the previous two years, Grade 3 students who attended the dual language programs had higher average TAKS Reading test scores (i.e., 0.89 points higher) and Mathematics test scores (i.e., 0.28 points higher) than their peers who attended the exit programs. 


\section{Reading and Mathematics Results for Grade 4 Students}

With respect to the 2008-2009 school year, a statistically significant difference was present in Grade 4 students' TAKS Reading raw scores, $t(15815.96)=9.93, p<.001, d=0.11$, trivial effect size, and in their TAKS Mathematics raw scores, $t(16185.39)=12.04, p<.001, d=0.13$, trivial effect size, by the type of bilingual education program in which they were enrolled. Grade 4 students who were enrolled in a dual language program had higher average TAKS Reading test scores (i.e., 0.93 points higher) and Mathematics test scores (i.e., 1.10 points higher) than did Grade 4 students in an exit program. Descriptive statistics for this analysis are presented in Table 2.

Table 2. Descriptive Statistics for Reading and Mathematics Scores by Bilingual Education Program for Grade 4 Students in the 2008-2009, 20092010, and 2010-2011 School Years

\begin{tabular}{|l|c|c|c|}
\hline $\begin{array}{l}\text { Academic Subject, School Year, and } \\
\text { Bilingual Education Program Type }\end{array}$ & n & M & SD \\
\hline Reading & & & \\
\hline $2008-2009$ & & & \\
\hline Exit & 40,355 & 28.98 & 8.54 \\
\hline Dual Language & 10,143 & 29.91 & 8.41 \\
\hline $2009-2010$ & & & \\
\hline Exit & 37,449 & 28.92 & 8.20 \\
\hline Dual Language & 16,413 & 30.70 & 7.93 \\
\hline $2010-2011$ & & & \\
\hline Exit & 36,210 & 28.78 & 8.46 \\
\hline Dual Language & 20,592 & 30.82 & 8.04 \\
\hline Mathematics & & & \\
\hline $2008-2009$ & & & \\
\hline Exit & 40,354 & 31.98 & 8.57 \\
\hline Dual Language & 10,134 & 33.09 & 8.17 \\
\hline $2009-2010$ & & & \\
\hline Exit & 37,490 & 32.45 & 7.91 \\
\hline Dual Language & 16,415 & 33.48 & 7.73 \\
\hline $2010-2011$ & & & \\
\hline Exit & 36,215 & 32.66 & 8.03 \\
\hline Dual Language & 20,583 & 33.57 & 7.83 \\
\hline
\end{tabular}

Regarding the 2009-2010 school year, a statistically significant difference was revealed in Grade 4 students' TAKS Reading raw scores, $t(32249.39)=$ 23.74, $p<.001, d=0.22$, small effect size, and in their TAKS Mathematics raw scores, $t(31992.16)=14.03, p<.001, d=0.13$, trivial effect size, by the type of bilingual education program in which they were enrolled. Higher average scores on the TAKS Reading test (1.78 points higher) and on the TAKS Mathematics test (1.02) were obtained by Grade 4 students who were enrolled in a dual language program than by their counterparts who were enrolled in an exit program. 
Concerning the 2010-2011 school year, a statistically significant difference was present in Grade 4 students' TAKS Reading raw scores, $t(44618.39)=28.59$, $p<.001, d=0.25$, and in their TAKS Mathematics raw scores, $t(43655.09)=$ $13.17, p<.001, d=0.11$, by the type of dual language program in which they were enrolled. The effect sizes for these two statistically significant differences were small and trivial, respectively. Congruent with the results for the previous two years, Grade 4 students who attended a dual language program had higher average TAKS Reading test scores (i.e., 2.04 points higher) and Mathematics test scores (i.e., 0.91 points higher) than their peers who attended an exit program.

\section{Reading and Mathematics Results for Grade 5 Students}

With respect to the 2008-2009 school year, a statistically significant difference was present in Grade 5 students' TAKS Reading raw scores, $t(10102.60)=12.61, p<.001, d=0.17$, trivial effect size, and in their TAKS Mathematics raw scores, $t(10757.01)=18.90, p<.001, d=0.25$, small effect size, by the type of bilingual education program in which they were enrolled. Grade 5 students who were enrolled in a dual language program had higher average TAKS Reading test scores (i.e., 1.63 points higher) and Mathematics test scores (i.e., 2.24 points higher) than did Grade 5 students in an exit program. Descriptive statistics for this analysis are presented in Table 3.

Table 3. Descriptive Statistics for Reading and Mathematics Scores by Bilingual Education Program for Grade 5 Students in the 2008-2009, 20092010, and 2010-2011 School Years

\begin{tabular}{|l|r|r|c|}
\hline $\begin{array}{l}\text { Academic Subject, School Year, and } \\
\text { Bilingual Education Program Type }\end{array}$ & $\mathbf{n}$ & $\mathbf{M}$ & SD \\
\hline Reading & & & \\
\hline 2008-2009 & & & \\
\hline Exit & 28,380 & 26.69 & 9.10 \\
\hline Dual Language & 6,970 & 28.32 & 9.83 \\
\hline $2009-2010$ & & & \\
\hline Exit & 28,866 & 28.61 & 9.06 \\
\hline Dual Language & 8,563 & 30.21 & 9.36 \\
\hline 2010-2011 & & & \\
\hline Exit & 26,223 & 28.89 & 8.88 \\
\hline Dual Language & 13,629 & 31.01 & 9.04 \\
\hline Mathematics & & & \\
\hline $2008-2009$ & & & \\
\hline Exit & 28,547 & 31.43 & 9.11 \\
\hline Dual Language & 6,866 & 33.67 & 8.73 \\
\hline $2009-2010$ & & & \\
\hline Exit & 28,864 & 30.25 & 10.28 \\
\hline Dual Language & 8,570 & 32.33 & 10.32 \\
\hline $2010-2011$ & & & \\
\hline Exit & 26,231 & 30.35 & 10.20 \\
\hline Dual Language & 13,627 & 32.74 & 9.94 \\
\hline
\end{tabular}


Regarding the 2009-2010 school year, a statistically significant difference was revealed in Grade 5 students' TAKS Reading raw scores, $t(13669.66)=$ 13.91, $p<.001, d=0.17$, trivial effect size, and in their TAKS Mathematics raw scores, $t(14006.63)=16.40, p<.001, d=0.20$, small effect size, by the type of bilingual education program in which they were enrolled. Higher average scores were obtained on the TAKS Reading test (1.59 points higher) and on the TAKS Mathematics test (2.08) by Grade 5 students who were enrolled in a dual language program than by their counterparts who were enrolled in an exit program.

Concerning the 2010-2011 school year, a statistically significant difference was present in Grade 5 students' TAKS Reading raw scores, $t(28162.52)=$ 22.52, $p<.001, d=0.24$, and in their TAKS Mathematics raw scores, $t(28221.86)=22.52, p<.001, d=0.24$, by the type of bilingual education program in which they were enrolled. The effect sizes for these two statistically significant differences were both small. Congruent with the results for the previous two years, Grade 5 students who attended a dual language program had higher average TAKS Reading test scores (i.e., 2.12 points higher) and Mathematics test scores (i.e., 2.39 points higher) than their peers who attended an exit program.

\section{Reading and Mathematics Results for Grade 6 Students}

With respect to the 2008-2009 school year, a statistically significant difference was present in Grade 6 students' TAKS Reading raw scores, $t(2501.76)=10.06, p<.001, d=0.30$, small effect size, and in their TAKS Mathematics raw scores, $t(2594.08)=12.87, p<.001, d=0.38$, small effect size, by the type of bilingual education program in which they were enrolled. Grade 6 students who were enrolled in a dual language program had higher average TAKS Reading test scores (i.e., 2.57 points higher) and Mathematics test scores (i.e., 3.38 points higher) than did Grade 6 students in an exit program. Descriptive statistics for this analysis are presented in Table 4. 
Table 4. Descriptive Statistics for Reading and Mathematics Scores by Bilingual Education Program for Grade 6 Students in the 2008-2009, 20092010, and 2010-2011 School Years

\begin{tabular}{|c|c|c|c|}
\hline $\begin{array}{l}\text { Academic Subject, School Year, and } \\
\text { Bilingual Education Program Type }\end{array}$ & $\mathbf{n}$ & $\overline{\mathbf{M}}$ & SD \\
\hline \multicolumn{4}{|l|}{ Reading } \\
\hline \multicolumn{4}{|l|}{$2008-2009$} \\
\hline Exit & 4,567 & 28.76 & 8.59 \\
\hline Dual Language & 1,469 & 31.34 & 8.51 \\
\hline \multicolumn{4}{|l|}{$2009-2010$} \\
\hline Exit & 4,674 & 28.18 & 9.08 \\
\hline Dual Language & 2,041 & 31.26 & 8.87 \\
\hline \multicolumn{4}{|l|}{$2010-2011$} \\
\hline Exit & 4,742 & 28.59 & 9.36 \\
\hline Dual Language & 1,881 & 32.54 & 8.33 \\
\hline \multicolumn{4}{|l|}{ Mathematics } \\
\hline \multicolumn{4}{|l|}{$2008-2009$} \\
\hline Exit & 4,570 & 31.26 & 9.09 \\
\hline Dual Language & 1,470 & 34.64 & 8.64 \\
\hline \multicolumn{4}{|l|}{$2009-2010$} \\
\hline Exit & 4,676 & 31.69 & 9.31 \\
\hline Dual Language & 2,039 & 34.95 & 9.03 \\
\hline \multicolumn{4}{|l|}{$2010-2011$} \\
\hline Exit & 4,742 & 31.85 & 9.30 \\
\hline Dual Language & 1,882 & 35.67 & 8.42 \\
\hline
\end{tabular}

Regarding the 2009-2010 school year, a statistically significant difference was revealed in Grade 6 students' TAKS Reading raw scores, $t(3969.29)=$ $13.10, p<.001, d=0.34$, small effect size, and in their TAKS Mathematics raw scores, $t(3991.06)=13.49, p<.001, d=0.36$, small effect size, by the type of bilingual education program in which they were enrolled. Higher average scores on the TAKS Reading test (3.10 points higher) and on the TAKS Mathematics test (3.26) were obtained by Grade 6 students who were enrolled in a dual language program than by their counterparts who were enrolled in an exit program.

Concerning the 2010-2011 school year, a statistically significant difference was present in Grade 6 students' TAKS Reading raw scores, $t(38450.00)=$ $16.76, p<.001, d=0.44$, and their TAKS Mathematics raw scores, $t(3787.68)$ $=16.14, p<.001, d=0.43$, by the type of bilingual education program in which they were enrolled. The effect sizes for these two statistically significant differences were both small. Congruent with the results for the previous two years, Grade 6 students who attended a dual language program had higher average TAKS Reading test scores (i.e., 3.94 points higher) and Mathematics test scores (i.e., 3.82 points higher) than their peers who attended an exit program. 


\section{Discussion}

In this research study, differences in the academic achievement (i.e., reading and mathematics) of English Language Learners as a function of the type of bilingual education program attended (i.e., dual language or exit program) were analyzed. Archival data for the 2008-2009, 2009-2010, 20102011 school years provided by the Texas Education Agency Public Education Information Management System were used for this analysis. Concerning the TAKS Reading scores, English Language Learners who were enrolled in the dual language programs consistently outperformed English Language Learners who were enrolled in exit programs in all 12 statistical analyses. Of interest is that as the grade level increased from Grade 3 to Grade 6, the average reading achievement gap (i.e., 2008-2009, 2009-2010, and 2010-2011 school years) between the two types of bilingual education programs increased. That is, the TAKS Reading average achievement gap between the two types of bilingual education programs was 0.75 points for Grade $3,1.58$ points for Grade $4,1.78$ points for Grade 5, and 3.20 points for Grade 6.

In reference to the TAKS Mathematics scores, English Language Learners who were enrolled in dual language programs consistently outperformed English Language Learners who were enrolled in exit programs in all statistical 12 analyses. Similar to the TAKS Reading results, as the grade level increased from Grade 3 to Grade 6, the mathematics achievement gap between the two types of bilingual education programs increased. The TAKS Mathematics gap for students in Grade 6 was 3.05, 2.95, and 3.54 points higher than the TAKS Mathematics achievement gap for students in Grade 3 for the 2008-2009, 20092010, and 2010-2011 school years, respectively. Regarding the increase in the average achievement gap between dual language programs and exit programs, as the grade level increased (i.e., Grades 3 through 6), the increase was 0.73 points higher for mathematics (i.e., 0.75 points for Grade 3, compared to 3.20 points for students in Grade 6) than it was for reading (i.e., 0.31 points for Grade 3, compared to 3.49 points for students in Grade 6).

In this investigation, students enrolled in dual language programs outperformed students who were enrolled in exit programs in reading and in mathematics in all 24 analyses. These findings are consistent with Baker's categorization of bilingual education programs, in which Baker (1990) suggested 10 types of bilingual education programs, categorizing them into weak forms of education for bilingualism, including the transitional exit programs among others, and strong forms of education for bilingualism and biliteracy, which, among others, included the dual language programs.

\section{Implications for Policy and for Practice}

English is the primary language in the state of Texas. Many students in Texas come from homes in which a language other than English is used as the basic way of communication. Public schools in Texas have the responsibility of providing an opportunity for English Language Learners to be able to speak, 
listen, write, and read English as the same level non-English Language Learners do. Because the needs of English Language Learners are not met in classes in which instruction takes place only in English (Texas Education Code, Title 2, 2012), the state of Texas has mandated school districts with an enrollment of 20 or more English Language Learners who speak the same native language, to offer bilingual or English as a Second Language education, allowing the equitable participation in schools for this group of students (Texas Administrative Code, Title 19, 2012).

The number of English Language Learners in the United States is steadily increasing (Garcia \& Miller, 2008). The academic achievement of English Language Learners has been documented to be consistently lower than the academic achievement of non-English Language Learners (DeJesus, 2008). This achievement gap between these two subgroups keeps growing with the years (Samson \& Collins, 2012). As a result, much attention has been provided regarding the quality of education received by Hispanic and Black students (August \& Shanahan, 2006). Moreover, federal law demands adequate support to English Language Learners in the development of their second language (Samson \& Collins, 2012).

In this research investigation, English Language Learners who participated in a dual language program outperformed English Language Learners who attended an exit program in all 24 analyses. These findings are supported by previous research conducted by DeJesus (2008), who compared the Language Arts academic achievement of a group of Grade 4 students (English Language Learners and non-English Language Learners) who had participated in a dual language program for five years, to the academic achievement of other students in the district who attended an exit program or a general education program. DeJesus (2008) noted that the scores of students enrolled in the dual language program were $22 \%$ higher than the scores of student enrolled in the exit programs, and $20 \%$ higher than the scores of students attending the general education programs. Therefore, policymakers, district, and school administrators are encouraged to consider the implementation of dual language programs as the best way to provide equal education opportunities.

\section{Suggestions for Future Research}

Because by 2025 one of every four students in the United States will be an English Language Learner (Ortiz et al., 2009), further investigation regarding the effectiveness of the different types of bilingual education programs in clearly warranted to enhance their academic success of this group of students. In this investigation, the effect of dual education programs and exit programs on English Language Learners attending Grades 3 through 6 was analyzed. However, researchers are encouraged to examine the effect of dual language and exit programs on students attending Grades 7 through 12.

Additionally, the effect of dual language and exit programs on areas other than academic achievement of English Language Learners, as well as the effect of dual language programs on areas other than academic achievement of non- 
English Language Learners was not analyzed. Therefore, a study in which the different advantages and disadvantages of these types of bilingual education programs is suggested. Furthermore, an investigation concerning collegereadiness rates of English Language Learners and non-English Language Learners who attended a dual language program, as well as of the English Language Learners who were enrolled in an exit program is recommended. Additionally, this proposed investigation could be enriched by a more extensive analysis of the effect of these types of bilingual programs on college readiness by ethnicity (i.e., Hispanic English Language Learners, White English Language Learners, Asian English Language Learners, Black English Language Learners, Hispanic non-English Language Learners, White nonEnglish Language Learners, Asian non-English Language Learners, and Black non-English Language Learners). Finally, research on the reasons why students attending dual language programs obtained higher scores than English Language Learners who were enrolled in exit programs is warranted. The reasons why the gap between dual language programs and exit programs was larger for mathematics than for reading also merits study.

\section{Conclusion}

Ethnic and linguistic diversity in public schools of the United States and in the state of Texas keep increasing each year. English Language Learners are the fastest growing student population in Grades K-12 (Zimmerman, 2010). Based on the results of this study, consistent results were present concerning the predominance of the dual language education programs. Of the 24 statistical analyses conducted, English Language Learners who attended a dual language program consistently had higher average reading and mathematics scores than English Language Learners who were enrolled in an exit program in all 24 analyses. Therefore, policymakers, districts, and school administrators are encouraged to consider the implementation of dual language programs as the best way to provide opportunities for equal education to English Language Learners.

\section{References}

August, D., \& Shanahan, T. (Eds.). (2006). Developing literacy in second-language learners. Mahwah, NJ: Erlbaum.

Baker, C. (1990). The effectiveness of bilingual education. Journal of Multilingual and Multicultural Development, 11(4), 269-277.

Baker, C. (2006). Foundations of bilingual education and bilingualism (4th ed.). Clevedon, UK: Multilingual Matters.

Cazden, C. B., \& Snow, C. E. (1990). English plus: Issues in bilingual education. Annals of the American Academy of Political and Social Science, 508. London, England: Sage.

Collier, V. P. (1992). A synthesis of studies examining long-term language minority 
student data on academic achievement. Bilingual Research Journal, 16, 187-212.

Crawford, J. (1989). Bilingual education: History, politics, theory, and practice (5th ed.). Trenton, NJ: Crane Publishing Company, Inc. Retrieved from https://classes. lt.unt.edu/Spring_2010/CECS_5420_020/lao0041/Assign\%203/

DeJesus, S. D. (2008). An astounding treasure: Dual language education in a public school setting. Centro Journal, 20(2), 192-217. Retrieved from http://www.goo gle.com/url? $\mathrm{sa}=\mathrm{t} \& \mathrm{rct}=\mathrm{j} \& \mathrm{q}=\&$ esrc $=\mathrm{s} \&$ source $=\mathrm{web} \& \mathrm{~cd}=2 \& \mathrm{ved}=0 \mathrm{CCcQFj} \mathrm{AB} \& u \mathrm{ur}$ $\mathrm{l}=\mathrm{http} \% 3 \mathrm{~A} \% 2 \mathrm{~F} \% 2 \mathrm{Fwww}$. redalyc.org\%2Fpdf\%2F377\%2F37712148010.pdf\&ei $=$ gaGgVMDOKou1ggS3gIPACw\&usg=AFQjCNFqk1_1pCpSvb6Enoasjiy6PBJw 7w\&bvm=bv.82001339, d.eXY

Flores, S. M., Batalova, J., \& Fix, M. (2012). The educational trajectories of English Language Learners in Texas. National Center on Immigrant Integration Policy. Retrieved from http://cccie.org/images/stories/TexasELLs.pdf

Fry, R. (2003). Hispanic youth dropping out of U.S. schools: Measuring the challenge. Washington, DC: Pew Hispanic Center. Retrieved from http://pewhispanic.org/ files/reports/19.pdf

Fry, R. (2008). The role of schools in the English Language Learner achievement gap. Washington, DC: Pew Hispanic Center.

Gallo, Y., Garcia, M., Pinuelas, L., \& Youngs, I. (2008). Crisis in the Southwest: Bilingual education program inconsistencies. Multicultural Education, 16, 10-17.

Garcia, E. E., \& Miller, L. S. (2008). Findings and recommendations of the National Task Force on Early Childhood Education for Hispanics. Child Development Perspectives, 2, 52-58.

García, O. (2011). The translanguaging of Latino kindergarteners. In Potowksi, K., \& Rothman, J. (Eds.), Bilingual youth: Spanish in English-speaking societies (pp. 33-55). Philadelphia, PA: John Benjamins Publishing Company.

Kerlinger, F. N. (1986). Foundations of behavioral research. Fort Worth, TX: Harcourt Brace Jovanovich.

Leos, K., \& Saavedra, L. (2010). A new vision to increase the academic achievement for English language learners and immigrant students. The Global Institute for Language and Literacy Development, 1-12. Retrieved from http://www.urban. org/publications/412265.html

Lindholm, K. J. (1991). Theoretical assumptions and empirical evidence for academic achievement in two languages. Hispanic Journal of Behavioral Sciences, 13(1), 3-17. doi:10.1177/07399863910131001

Lindholm-Leary, K. J. (2001). Dual language education. Clevedon, UK: Multilingual Matters.

Lindholm-Leary, K. J. (2012). Success and challenges in dual language education. Theory Into Practice, 51, 256-262. doi:10.1080/00405841.2012.726053

Mackey, W. F. (1970). A typology of bilingual education. Foreign Language Annals, 3, 596-606. doi:10.1111/j.1944-9720.1970.tb01307.x

Martinez, R. M. (2014). Differences in student achievement between early-exit and late-exit bilingual programs: A multiyear, statewide investigation (Doctoral thesis). Available from ProQuest Dissertations and Theses database. (UMI No. 3580934)

Morison, S. H. (1990). A Spanish-English dual-language program in New York City. In C. B. Cazden, \& C. E., Snow (Ed.), Annals of the American Academy of Political and Social Science, 508 (pp. 160-169). London, England: Sage.

Ortiz, T., Pagan, M., Warford, J., \& Wendell, L. (2009). Closing the ELL achievement gap: A leader's guide to making schools effective for culturally and linguistically diverse students. International Center for Leadership in Education, Inc. 
Retrieved from http://www.leadered.com/pdf/Closing\%20ELL\%20Gap\%20kit\% 20excerpt.pdf

Ramirez, J. D. (1986). Comparing structured English immersion and bilingual education: First-year results of a national study. American Journal of Education, $95,122-148$.

Rennie, J. (1993). ESL and bilingual program models. ERIC Clearinghouse on Languages and Linguistics, 12(1). Retrieved from http://www.ericdigests.org/19 94/esl.htm

Rhodes, R. L., Ochoa, S. H., \& Ortiz, S. O. (2005). Assessing culturally and linguistically diverse students: A practical guide. New York, NY: The Guilford Press.

Samson, J. F., \& Collins, B. A. (2012, April). Preparing all teachers to meet the needs of English language learners: Applying research to policy and practice for teacher effectiveness. Center for American Progress. Retrieved from http://files.eric.ed. gov/fulltext/ED535608.pdf

Texas Administrative Code. (2012). Chapter 89. Adaptations for special populations subchapter BB. Commissioner's Rule Concerning State Plan for Educating English Language Learners. Retrieved from http://texreg.sos.state.tx.us/public/ readtac\$ext.TacPage?sl=T\&app=9\&p_dir $=P \& p \_r l o c=156464 \& p \_t l o c=\& p \_p l o c=$ $1 \& \mathrm{pg}=2 \& \mathrm{p} \_\mathrm{tac}=\& \mathrm{ti}=19 \& \mathrm{pt}=2 \& \mathrm{ch}=89 \& \mathrm{rl}=1203$

Texas Education Agency. (2014). Academic Excellence Indicator System: Archives. Retrieved from http://ritter.tea.state.tx.us/perfreport/aeis/

Texas Education Code. (2012). Title 2. Public education. Subtitle B. Bilingual education and special language programs Texas education code. Chapter 29. Educational programs. Retrieved from http://www.elltx.org/29_051.html

Tong, F., Irby, B. J., Lara-Alecio, R., \& Mathes, P. (2008). English and Spanish acquisition by Hispanic second graders in developmental bilingual programs: A 3-year longitudinal randomized study. Hispanic Journal of Behavioral Sciences, $30,500-529$.

Yturriago, J. A., \& Garcia, A. G. (2014). Preparing bilingual teacher candidates: A linguistic conundrum in a changing political landscape. International Journal of Humanities and Social Science, 2(4), 76-85.

Zimmerman, L. W. (2010). ESL, EFL, \& bilingual education: Exploring historical, sociocultural, linguistic, and instructional foundations. Charlotte, NC: Information Age Publishing, Inc. 
